\title{
Euproops danae (Belinuridae) cluster confirms deep origin of gregarious behaviour in xiphosurids
}

\section{Скопление Eирroops danae (Belinuridae) подтверждает давнее происхождение грегарного поведения у мечехвостов}

\author{
Russell D.C. Bicknell ${ }^{*}$, Stephen Pates ${ }^{2}$, Mark L. Botton ${ }^{3}$

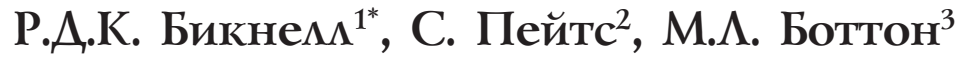 \\ ${ }^{1}$ Palaeoscience Research Centre, School of Environmental and Rural Science, University of New England, Armidale, New South Wales, \\ 2351, Australia. \\ ${ }^{2}$ Museum of Comparative Zoology and Department of Organismic and Evolutionary Biology, Harvard University, 26 Oxford Street, \\ Cambridge, MA 02138, USA. \\ ${ }^{3}$ Department of Natural Sciences, Fordham University, New York, NY 10023, USA. \\ * Corresponding author: rdcbicknell@gmail.com
}

KEY WORDS: Euproops danae, clustering, gregarious behaviour, Carboniferous, evolutionary stasis.

КЛЮЧЕВЫЕ СЛОВА: Euproops danae, скопление, грегарное поведение, каменноугольный период, эволюционный стазис.

ABSTRACT. Xiphosurids are archetypal marine arthropods that have received considerable research interest from both biologists and palaeontologists. Mating clusters of extant horseshoe crabs have informed research on clustering in other fossil arthropods, such as trilobites. Furthermore, the evolutionary stasis exhibited by horseshoe crabs suggests that fossil xiphosurids may also have mated in clusters. However, no body fossil evidence has been presented to support this idea. Here, we document a cluster of seven Euproops danae (Meek et Worthen, 1865) specimens preserved on the same bedding plane of Pennsylvanian-aged Farrington Group siltstone. These specimens record potential reproductive strategies of belinurids that are comparable to extant counterparts. This gregarious behaviour may have decreased the impact of predation and/or contributed to genetic diversity. The cluster ultimately highlights a further example of xiphosurid evolutionary stasis.

How to cite this article: Bicknell R.D.C., Pates S., Botton M.L. 2019. Euproops danae (Belinuridae) cluster confirms deep origin of gregarious behaviour in xiphosurids // Arthropoda Selecta. Vol.28. No.4. P.549555. doi: 10.15298/arthsel. 28.4.07

РЕЗЮМЕ. Мечехвосты Хiphosurida - архетипические морские членистоногие, представляющие значительный интерес для исследований биологов и палеонтологов. Наличие скоплений при спаривании у рецентных мечехвостов привело к исследованию аналогичных группировок у ископаемых членистоногих, таких как трилобиты. Более того, вследствие эволюционного стазиса, проявляемого мечехвостами, можно предположить, что ископаемые Xiphosurida также спариваются в скоплениях. Тем не менее, до сих пор это предположение не было подтверждено ископаемыми находками. Здесь задокументировано скопление семи Euproops danae (Meek et Worthen, 1865), сохранившихся на той же поверхности напластования алевролита группы Фаррингтон пенсильванского возраста. Эти экземпляры проявляют потенциальную репродуктивную стратегию Belinuridae, которая сравнима с таковой рецентных форм. Грегарное поведение может уменьшить вероятность нападения хищников и/или быть связанным с генетическим разнообразием, и представляет собой еще один пример эволюционного стазиса Xiphosurida.

\section{Introduction}

True horseshoe crabs (Chelicerata: Xiphosurida) are arguably the most iconic group of extant marine chelicerates [Shuster Jr., 1982; Bicknell et al., 2018a; Bicknell, Pates, 2019a]. The domed, crescent-shaped prosoma, rounded to trapezoidal opisthosoma, and elongate telson give the extant taxa an archaic appearance [Rudkin et al., 2008; Rudkin, Young, 2009; Bicknell et al., 2018b; Bicknell, Pates, 2019b]. This morphology, coupled with a stunning fossil record and exhibition of apparent evolutionary stasis, has driven palaeontological interest in xiphosurids [Babcock et al., 2000; Anderson, Shuster Jr., 2003; Kin, Błażejowski, 2014; Bicknell et al., 2019a, d]. Due to their phylogenetic position, extant horseshoe crabs are often used as modern analogues to explore facets of extinct arthropod groups. In particular, the annual spawning events of the American horseshoe crab, Limulus polyphemus (Linnaeus, 1758), are compared to clusters of fossil arthropods such as trilobites [Shuster Jr., 1982; Hughes, Cooper, 
1999; Paterson et al., 2008; Brockmann et al., 2000; Gutiérrez-Marco et al., 2009; Shuster Jr., Sekiguchi, 2009; Bicknell et al., 2019c] and eurypterids [Braddy, 2001; Vrazo, Braddy, 2011]. Similarities between clusters of articulated trilobites and the patterns of horseshoe crab spawning have been used to suggest that, in exceptional circumstances, trilobites exhibited gregarious behaviour [Hughes, Cooper, 1999; Karim, Westrop, 2002; Paterson et al., 2008; Gutiérrez-Marco et al., 2009; Brett, 2015; Bicknell et al., 2019c]. However, no record of fossil horseshoe crab clusters are known. One might therefore ask: has horseshoe crab spawning arisen recently in their evolutionary history, or does it have a deeper origin in their fossil record that has simply not been reported. The only records of multiple fossil horseshoe crab specimens preserved on a same bedding plane are Ambrose \& Romano [1972] and unfigured discussions in Fisher [1979]. Here, we reconsider the Ambrose \& Romano [1972] slab that preserves specimens of the belinurid Euproops danae (Meek et Worthen, 1865) and, in doing so, discuss the first record of a fossil horseshoe crab cluster.

\section{Methods and Materials}

A slab of silty mudstone from the Farrington Group, collected from within a coal spoil heap in Sommerset, England, was considered. It has limited geological context, but is considered Westphalian D in age [Ambrose, Romano, 1972]. The authors of the original description assigned the seven specimens on the slab to Euproops kilmersdonensis Ambrose et Romano, 1972. This taxon was later synonymised with $E$. danae [Anderson, 1994]. The slab, housed in the Natural History Museum (NHMUK PI In 61012-61018), was photographed with a Canon EOS 5DS R under normal light. Carapace length (excluding telson) and prosoma-opisthosoma joint width measurements were taken for 5 specimens using ImageJ to explore possible patterns in specimen size (Addition 1). Two specimens (NHMUK PI In 61014 and NHMUK PI In 61018) are not preserved completely enough for these measurements.

\section{Results}

Five of the seven Euproops danae specimens (NHMUK PI In 61012, 61013, 61015, 61016, 61017) are preserved as complete prosoma and opisthosoma (Fig. 1). The telson is completely preserved in NHMUK PI In 61012 (Fig. 2A) and NHMUK PI In 61016 (Fig. 3A), partly preserved in NHMUK PI In 61015 (Fig. 2D), and absent in NHMUK PI In 61013 (Fig. 2B) and NHMUK PI In 61017 (Fig. 3B). Specimens NHMUK PI In 61014 (Fig. 2C) and NHMUK PI In 61018 (Fig. 3C) are partly preserved. NHMUK PI In 61014 (Fig. 2C) lacks the posterior right prosoma and the left opisthosomal side. NHMUK PI In 61018 (Fig. 3C) preserved the prosoma but lacks the left opisthosomal side. As Ambrose \& Romano [1972] noted, the speci- mens lack an obvious orientation, although at least five specimens (NHMUK PI In 61013, 61015, 61016, 61017, 61018; Figs 1A, B, 2B, D, 3A-C) are aligned with the slab's shorter axis. Carapace length measurements ranged between $24.8-27.5 \mathrm{~mm}$ and prosomaopisthosoma joint width measurement ranged between 20.0-27.9 $\mathrm{mm}$. These points plot into two distinct groups (Fig. 4).

\section{Discussion}

Preservation of multiple horseshoe crab specimens on the same bedding plane is definitely unusual and allowed Ambrose \& Romano [1972] to explore intraspecific variation. Here, the significance of the cluster itself is considered. Fisher [1979] suggested that the preservation of multiple specimens on the same slab recorded the imprisonment of Euproops danae within tree trunks, where the trunks functioned as pitfall traps. However, one would expect specimens to be preserved in different bedding planes, unless all individuals fell in at exactly the same time; an outcome that seems unparsimonious. As NHMUK PI In 61012-61018 are preserved on the same bedding plane, and as separate specimens, we suggest that the cluster records gregarious behaviour, such as mating or moulting, that was potentially preserved by a storm event and rapidly buried [Speyer, Brett, 1985; Karim, Westrop, 2002; Paterson et al., 2008; Brett et al., 2012; Brett, 2015]. The articulated nature of NHMUK PI In 61012-61018 precludes a moulting event [Vrazo, Braddy, 2011], but likely the lack of preferential specimen orientation, and similarity to clusters of extant xiphosurids suggests that the slab records a mating aggregation (sensu Gutiérrez-Marco et al., 2009). It is also interesting to note that the brackish palaeoenvironment that preserved this cluster is comparable to the environment the smallest extant taxon - Carcinoscorpius rotundicauda [Latreille, 1802] — spawns: "brackish estuaries and rivers in muddy sand and mangrove swamps" [Brockmann, Smith, 2009: 200; Fairuz-Fozi et al., 2018].

The mating system in extant horseshoe crabs has been reviewed at length (see Brockmann, 1990, 2003; Brockmann et al., 2000, 2015; Brockmann, Smith, 2009; references therein), and several common patterns have emerged. Spawning behaviour in all extant species is often synchronized to the lunar cycle, with the largest number of animals typically nesting on the full and new moon high tides. Modified prosomal appendages (claspers) on the male are used to attach to the opisthosoma of the female. After amplexus, the male places his gonopores close to the female's eggs to facilitate fertilization as she deposits the eggs into the substrate. Two pairs of claspers are found in the Asian horseshoe crabs [Carcinoscorpius rotundicauda, Tachypleus gigas (Müller, 1785) and T. tridentatus (Leach, 1819)], whereas Limulus polyphemus only has one pair of claspers. Botton et al. [1996] theorised that the double claspers in $T$. tridentatus are an adaptation to 

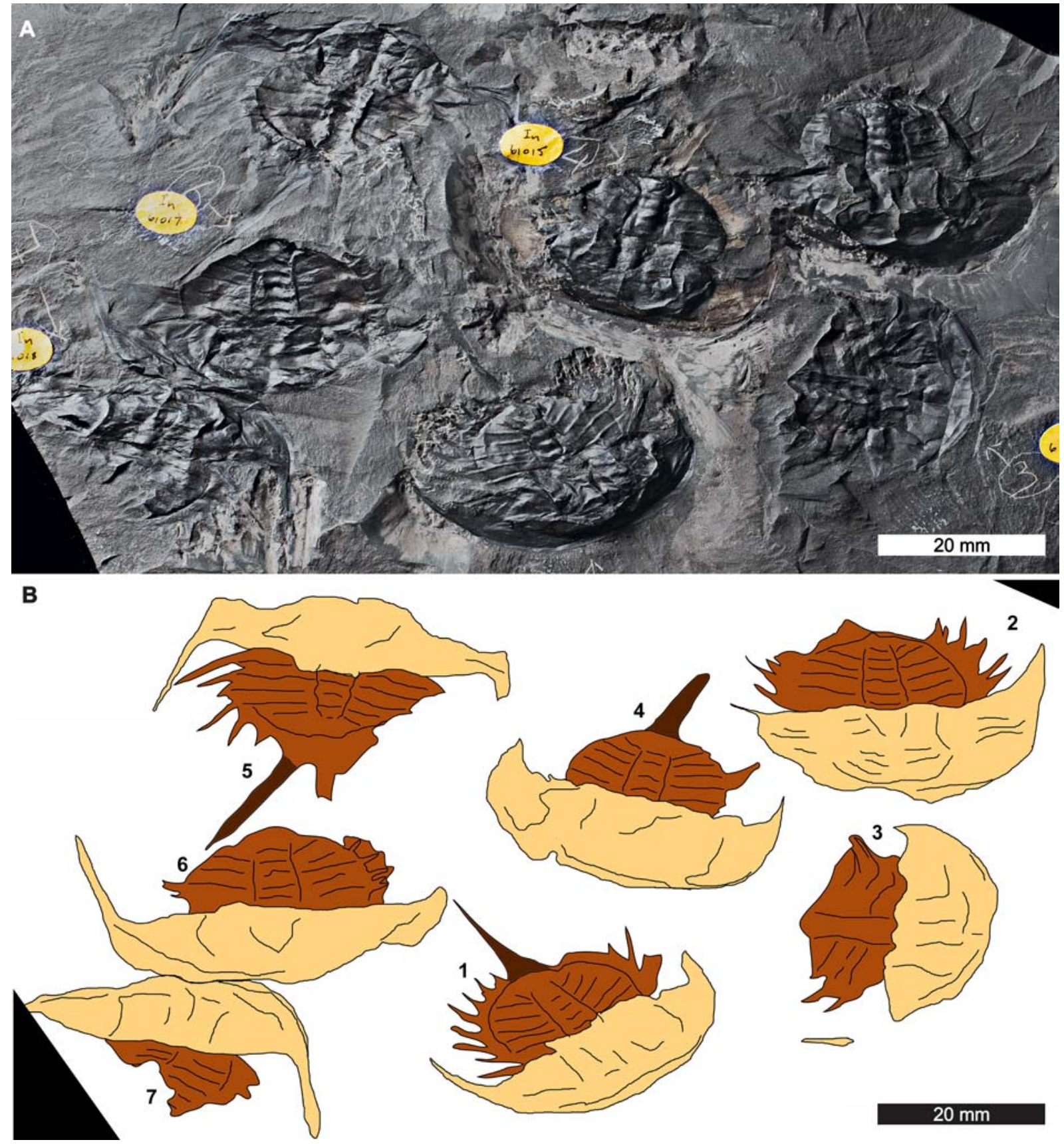

Fig. 1. Complete slab showing the seven specimens (NHMUK PI In 61012-61018). A - photograph of complete slab; B - line drawings of all specimens. 1 - NHMUK PI In 61012; 2 - NHMUK PI In 61013; 3 - NHMUK PI In 61014; 4 - NHMUK PI In 61015; 5 - NHMUK PI In 61016; 6 - NHMUK PI In 61017; 7 - NHMUK PI In 61018. Image credit: (A) Lucie Goodayle and the Natural History Museum, London.

Рис. 1. Целый кусрк породы с семью экземплярами (NHMUK PI In 61012-61018). A - фото целого куска породы; В прорисовки всех экземпляров. 1 - NHMUK PI In 61012; 2 - NHMUK PI In 61013; 3 - NHMUK PI In 61014; 4 - NHMUK PI In 61015; 5 - NHMUK PI In 61016; 6 - NHMUK PI In 61017; 7 - NHMUK PI In 61018. Любезно предоставлено Lucie Goodayle и Музеем естественной истории (Лондон) (А).

prolonged amplexus. Conversely, L. polyphemus satellite males are often found in association with amplexed pairs [Brockmann, Smith, 2009; Brockmann et al., 2015] but this phenomenon is seldom observed in the Asian species [Botton et al., 1996; Brockmann, Smith, 2009].
Reproduction in extant horseshoe crabs is a dangerous event as predation by gulls and the possibility of being stranded can result in mortality [Botton, Loveland, 1989]. The threat from predators can be decreased through mass spawning and clustering and Euproops danae would have benefited from this defence strategy 

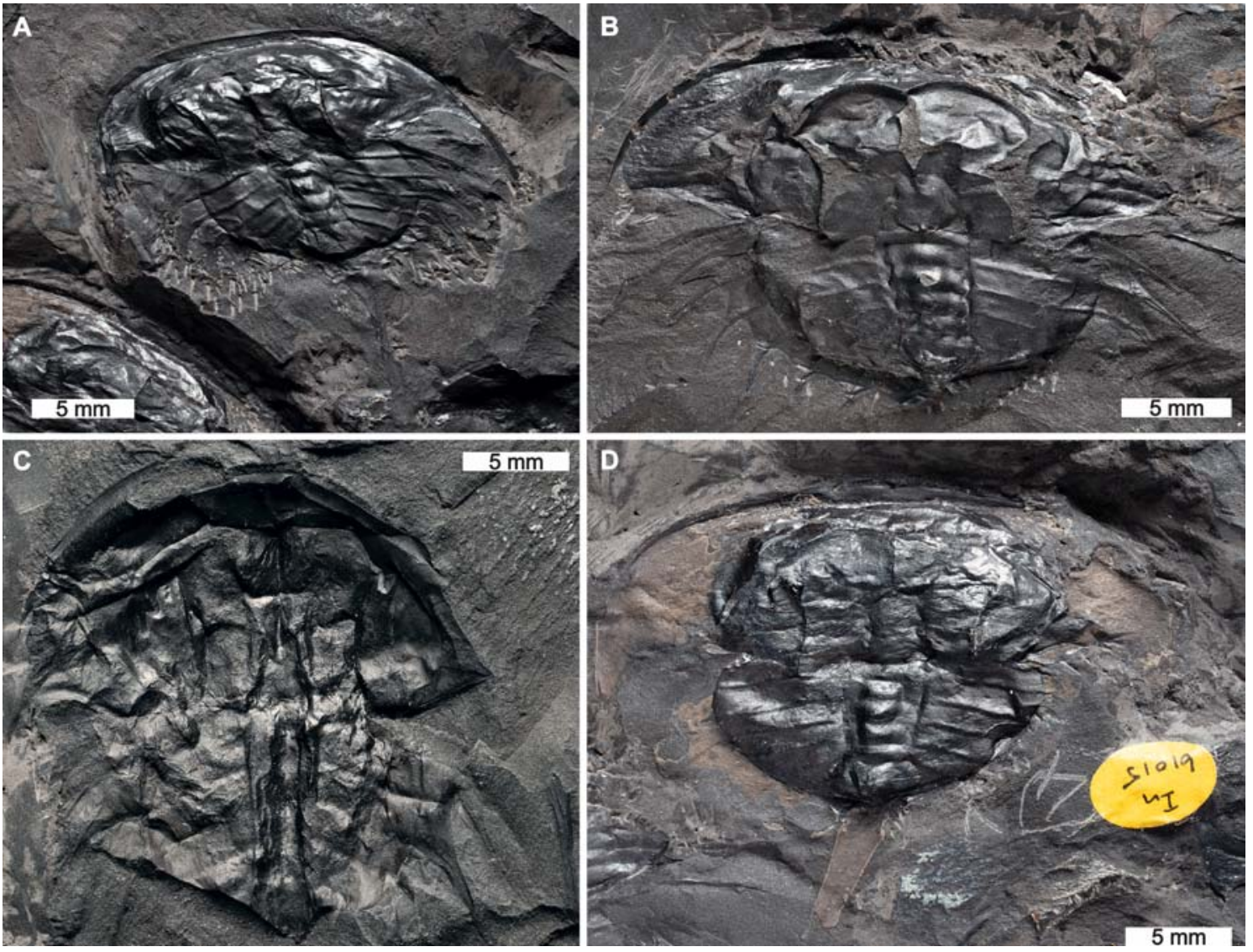

Fig. 2. Euproops danae specimens NHMUK PI In 61012-61015. A - NHMUK PI In 61012; B - NHMUK PI In 61013; C NHMUK PI In 61014; D - NHMUK PI In 61015. Image credit: (A-D) Lucie Goodayle and the Natural History Museum, London.

Рис. 2. Экземпляры Euproops danae NHMUK PI In 61012-61015. A — NHMUK PI In 61012; B - NHMUK PI In 61013; C — NHMUK PI In 61014; D - NHMUK PI In 61015. Любезно предоставлено Lucie Goodayle и Музеем естественной истории (Лондон) (A-D).
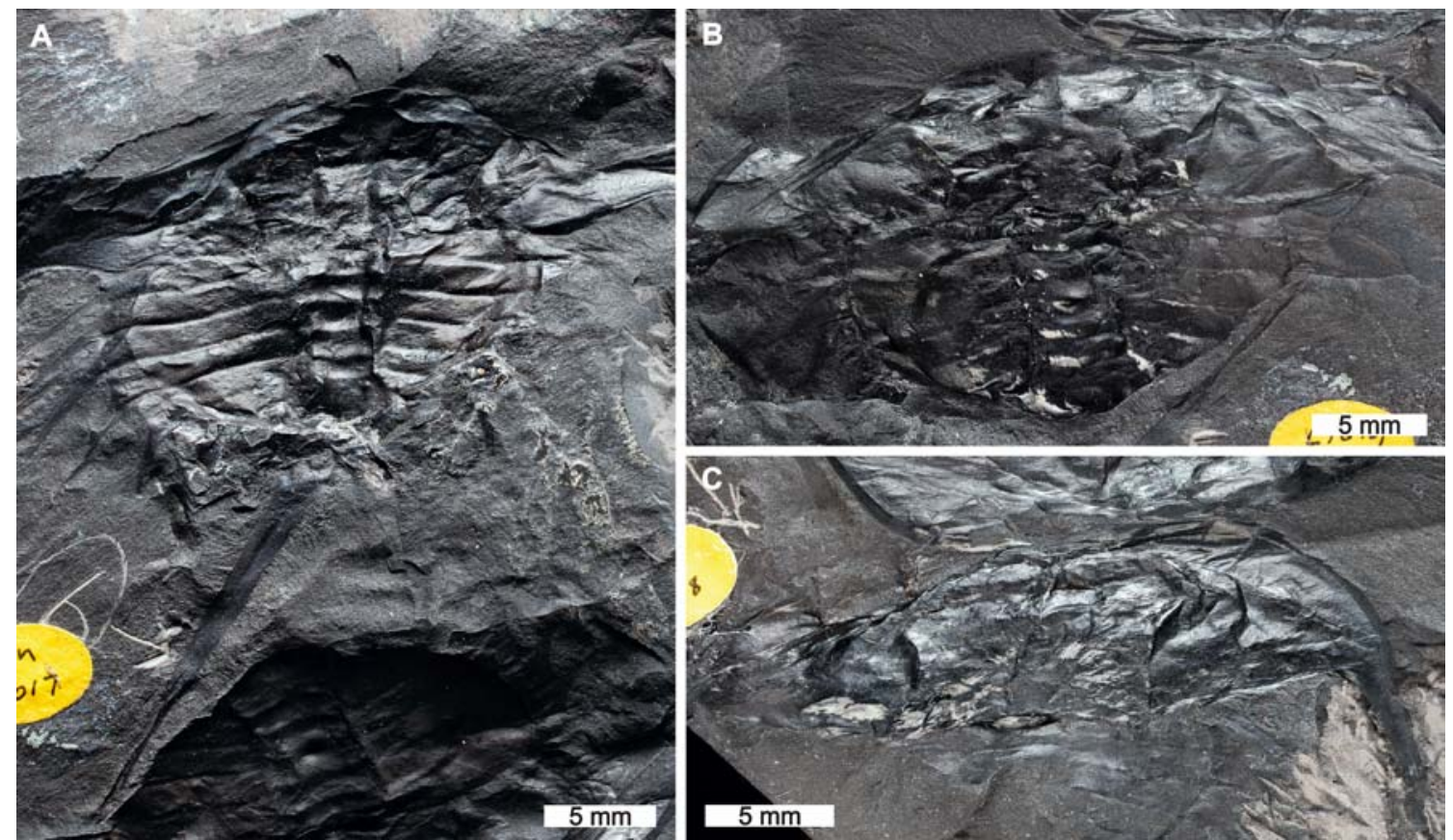

Fig. 3. Euproops danae specimens NHMUK PI In 61016-61018. A — NHMUK PI In 61016; B — NHMUK PI In 61017; C NHMUK PI In 61018. Image credit: (A-C) Lucie Goodayle and the Natural History Museum, London.

Рис. 3. Экземпляры Euproops danae NHMUK PI In 61016-61018. A - NHMUK PI In 61016; B - NHMUK PI In 61017; C NHMUK PI In 61018. Любезно предоставлено Lucie Goodayle и Музеем естественной истории (Лондон) (A-C). 


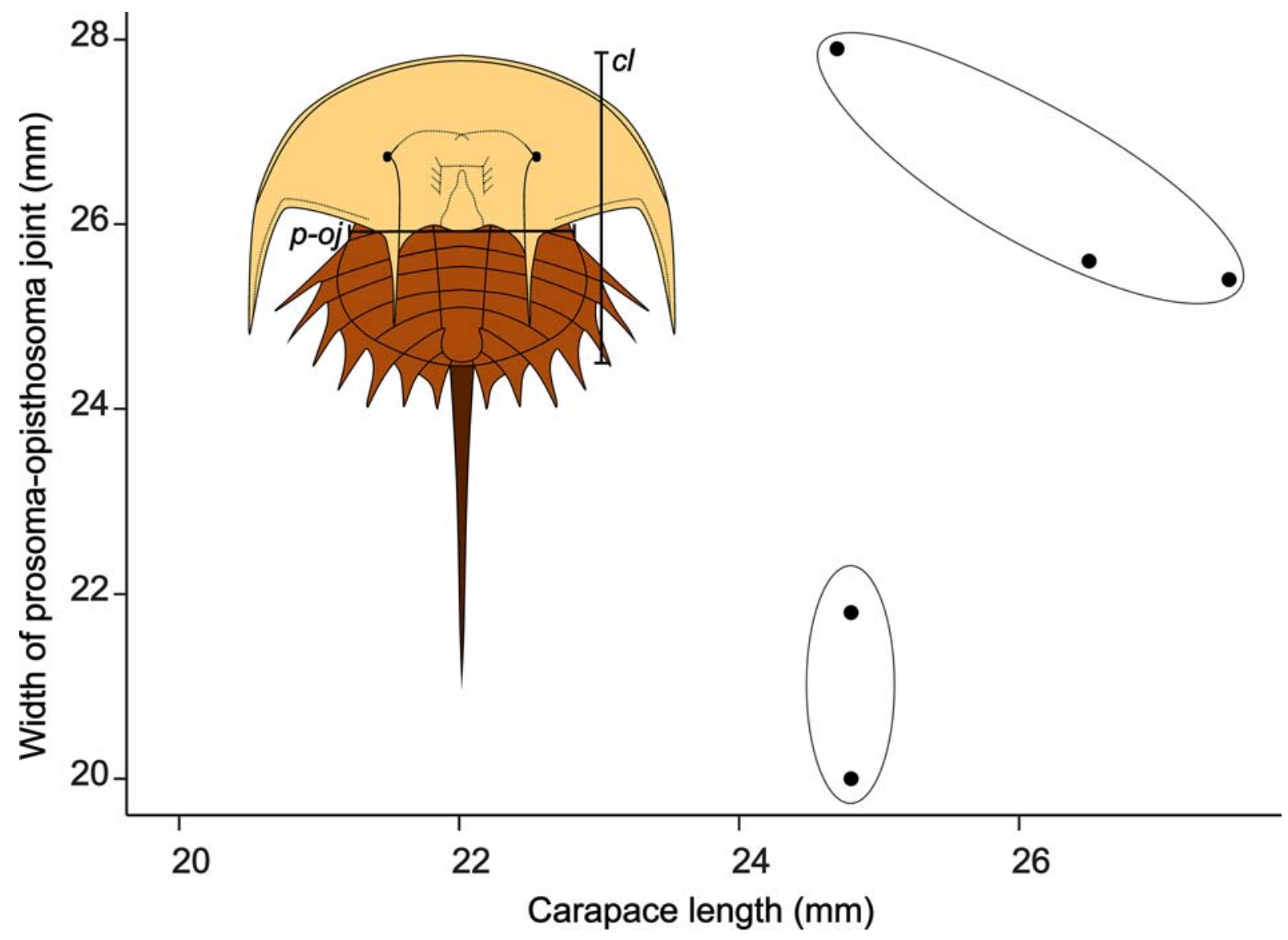

Fig. 4. Scatter plot of the five measured specimens and a reconstruction of Euproops danae. The two clusters are putative evidence for sexual dimorphism. Abbreviations: $p$-oj — prosoma-opisthosoma join; $\mathrm{cl}$ - carapace length (excluding telson).

Рис. 4. График промеров (диаграмма рассеивания) пяти экземпляров и реконструкция Euproops danae. Два кластера возможно свидетельствуют о половом диморфизме. Сокращения: $p-o j-$ сочленение просомы и опистосомы; $c l$ - длина карапакса (без тельсона).

giving similar safety in numbers (see discussion on predation in Fisher, 1977; Bicknell et al., 2018b). The record of gregarious behaviour in body specimens here adds support to previously documented trace fossil evidence of mass spawning (see Mujal et al., 2018). An alternative hypothesis for the evolution of clustering relates to the possible benefits of multiple paternity: sperm contributed by several males, as seen in typical clusters of Limulus polyphemus, a strategy which enhances genetic diversity [Brockmann et al., 2000].

The studied slab, and associated reproductive behaviour, is a further example of evolutionary stasis exhibited by horseshoe crabs [Fisher, 1984; Kin, Błażejowski, 2014; Bicknell et al., 2018a, b]. While the morphological similarity of extant horseshoe crab to ancestral xiphosurids is well-established (e.g., Fisher, 1984; Anderson, Shuster Jr., 2003; Rudkin et al., 2008; Rudkin, Young, 2009; Bicknell et al., 2018b, 2019a; Bicknell, Pates, 2019a), it also now seems quite likely that intertidal spawning and amplexus behaviour are also ancient. Diedrich [2011] interpreted the Kouphichnium Nopsca, 1923 ichnogenus found in the Middle Triassic from Bernburg, Germany as records of adult horseshoe crabs in an intertidal area during mating activity; of particular interest is a set of tracks that appears to record an amplexed pair. Related to this is the recently documented Yunnanolimulus luopingensis Zhang, Hu, Zhou, Lü et Bai, 2009 specimens from the Middle Triassic in Yunnan Province, China [Hu et al., 2017] that record well-preserved paired claspers with similar morphology to those seen in extant Carcinoscorpius rotundicauda. They suggest that the more highly modified and more bulbous claspers in Tachypleus and Limulus are more recently evolved.

As sexual dimorphism has been noted in fossil horseshoe crab taxa [Bicknell et al., 2019a], it is worth considering the topic in the context of the studied slab. The two loosely defined groups in bivariate space (Fig. 4) suggest a possible combination of male and female specimens; a possibility that has been suggested for Euproops danae from the Pennsylvanian-aged Mazon Creek fauna (Illinois, USA) [Haug, Rötzer, 2018]. However, we are cautious in assigning much meaning to these groups as only five specimens were assessed, the taphonomic alteration will have introduced error into the data (see the excellent discussion in Tashman, et 
al., 2019), and definite sexual dimorphic features such as modified anterior walking legs are unknown to the studied specimens [Shuster Jr., 1982; Bicknell et al., 2018a, 2019a]. Further specimens from the Farrington Group, ideally showing appendage data, may therefore support the notion of two genders and further highlight sexual dimorphism within fossil horseshoe crabs. One final consideration is given to a comment in Shpinev [2017] who suggested that the co-occurrence of Euproops with Bellinurus Pictet, 1846 records the morphological, potentially sexually dimorphic, extremes of the same organism. Further studies of the Russian deposits outlined in Shpinev [2017], and indeed Belinuridae in general, are needed to determine if the two genera do represent sexual dimorphism in fossil xiphosurids.

\section{Acknowledgements}

This research was supported by funding from an Australian Postgraduate Award (to R.D.C.B.), a Charles Schuchert and Carl O. Dunbar Grants-in-Aid award (to R.D.C.B.), a James R. Welch Scholarship (to R.D.C.B.), a University of New England ostdoctoral Fellowship (to R.D.C.B.), a Betty Mayne Scientific Research Fund (to R.D.C.B.), and an Alexander Agassiz Postdoctoral Fellowship (to S.P). We thank Lucie Goodayle and the Natural History Museum, London for images of the studied specimens, and Claire Mellish for access to material. Finally we thank Serge V. Naugolnykh for his helpful review.

\section{References}

Ambrose L., Romano M. 1972. New Upper Carboniferous Chelicerata (Arthropoda) from Somerset, England // Palaeontology. Vol.15. No.4. P.569-578.

Anderson L.I. 1994. Xiphosurans from the Westphalian D of the Radstock Basin, Somerset Coalfield, the South Wales Coalfield and Mazon Creek, Illinois // Proceedings of the Geologists' Association. Vol.105. No.4. P.265-275.

Anderson L.I., Shuster Jr., C.N. 2003. Throughout geologic time: where have they lived // Shuster Jr., C.N., Barlow R.B., Brockmann H.J. (eds.). The American Horseshoe Crab. Cambridge: Harvard University Press. P.189-223

Babcock L.E., Merriam D.F., West R.R. 2000. Paleolimulus, an early limuline (Xiphosurida), from Pennsylvanian-Permian Lagerstätten of Kansas and taphonomic comparison with modern Limulus // Lethaia. Vol.33. No.3. P.29-141.

Bicknell R.C.B., Brougham T., Charbonnier S., Sautereau F., Hitij T., Campione N.E. 2019a. On the appendicular anatomy of the xiphosurid Tachypleus syriacus and the evolution of fossil horseshoe crab appendages // The Science of Nature. Vol.106. No.7. doi:10.1007/s00114-019-1629-6

Bicknell R.C.B., Klinkhamer A.J., Flavel R.J., Wroe S., Paterson J.R. 2018a. A 3D anatomical atlas of appendage musculature in the chelicerate arthropod Limulus polyphemus // PLoS ONE. Vol.13. No.2. P.e0191400.

Bicknell R.C.B., Lustri L., Brougham T. 2019b. Revision of 'Bellinurus' carteri (Chelicerata: Xiphosura) from the Late Devonian of Pennsylvania, USA // Comptes Rendus Palevol. doi: 10.1016/j.crpv.2019.08.002

Bicknell R.C.B., Pates S. 2019a. Abnormal extant xiphosurids in the Yale Peabody Museum Invertebrate Zoology collection // Bulletin of the Peabody Museum of Natural History. Vol.60. No.1. P.41-53.

Bicknell R.C.B., Pates S. 2019b. Xiphosurid from the Tournasian (Carboniferous) of Scotland confirms deep origin of Limuloidea // Scientific Reports. Vol.9. P.17102.
Bicknell R.C.B, Pates S., Botton M.L. 2018b. Abnormal xiphosurids, with possible application to Cambrian trilobites // Palaeontologia Electronica. Vol.21. No.2. P.1-17.

Bicknell R.C.B., Paterson J.R., Hopkins M.J. 2019c. A trilobite cluster from the Silurian Rochester Shale of New York: predation patterns and possible defensive behavior // American Museum Novitates. Vol.39. No.3937. P.1-16.

Bicknell R.C.B., Žalohar J., Miklavc P., Celarc B., Križnar M., Hitij T. 2019d. A new limulid genus from the Strelovec Formation (Middle Triassic, Anisian) of northern Slovenia // Geological Magazine. doi:10.1017/S0016756819000323

Botton M.L., Loveland R.E. 1989. Reproductive risk: high mortality associated with spawning by horseshoe crabs (Limulus polyphemus) in Delaware Bay, USA // Marine Biology. Vol.101. No.2. P.143-151.

Botton M.L., Shuster Jr., C.N., Sekiguchi K., Sugita H. 1996. Amplexus and mating behavior in the Japanese horseshoe crab, Tachypleus tridentatus // Zoological Science. Vol.13. No.1. P.151-159.

Braddy S.J. 2001. Eurypterid palaeoecology: palaeobiological, ichnological and comparative evidence for a 'mass-moult-mate' hypothesis // Palaeogeography, Palaeoclimatology, Palaeoecology. Vol.172. No.1-2. P.115-132.

Brett C.E. 2015. Stratigraphy and depositional environments of the Rochester Shale in western New York // Chinnici P., Smith K. (eds.). The Silurian Experience. Rochester, NY: Primitive Worlds. P.36-68.

Brett C.E., Zambito III, J.J., Hunda B.R., Schindler E. 2012. MidPaleozoic trilobite Lagerstätten: Models of diagenetically enhanced obrution deposits // Palaios. Vol.27. No.5. P.326-345.

Brockmann H.J. 1990. Mating behavior of horseshoe crabs, Limulus polyphemus // Behaviour. Vol.114. No.1. P.206-220.

Brockmann H.J. 2003. Nesting behavior, a shoreline phenomenon // Shuster Jr., C.N., Barlow R.B., Brockmann H.J. (eds.). The American Horseshoe Crab. Cambridge, MA: Harvard University Press. P.33-49.

Brockmann H.J., Johnson S.L., Smith M.D., Sasson D. 2015. Mating tactics of the American horseshoe crab (Limulus polyphemus) // Carmichael R.H., Botton M.L., Shin P.K.S., Cheung S.G. (eds.). Changing Global Perspectives on Horseshoe Crab Biology, Conservation and Management. Switzerland: Springer International. P.321-351.

Brockmann H.J., Nguyen C., Potts W. 2000. Paternity in horseshoe crabs when spawning in multiple-male groups // Animal Behaviour. Vol.60. No.6. P.837-849.

Brockmann H.J., Smith M.D. 2009. Reproductive competition and sexual selection in horseshoe crabs // Tanacredi J.T., Botton M.L., Smith D.R. (eds.). Biology and Conservation of Horseshoe Crabs. New York: Springer. P.199-221.

Diedrich C.G. 2011. Middle Triassic horseshoe crab reproduction areas on intertidal flats of Europe with evidence of predation by archosaurs // Biological Journal of the Linnean Society. Vol.103. No.1. P.76-105.

Fairuz-Fozi N., Satyanarayana B., Zauki N.A.M., Muslim A.M., Husain M.-L., Ibrahim S., Nelson B.R. 2018. Carcinoscorpius rotundicauda (Latreille, 1802) population status and spawning behaviour at Pendas coast, Peninsular Malaysia // Global Ecology and Conservation. Vol. 15. P.e00422.

Fisher D.C. 1977. Functional significance of spines in the Pennsylvanian horseshoe crab Euproops danae // Paleobiology. Vol.3. No.2. P.175-195.

Fisher D.C. 1979. Evidence for subaerial activity of Euproops danae (Merostomata, Xiphosurida) // Nitecki M.H. (ed.). Mazon Creek Fossils. New York: Elsevier. P.379-447.

Fisher D.C. 1984. The Xiphosurida: archetypes of bradytely? // Eldredge N., Stanley S.M. (eds.). Living fossils. New York: Springer. P.196-213.

Gutiérrez-Marco J.C., Sá A.A., García-Bellido D.C., Rábano I., Valério M. 2009. Giant trilobites and trilobite clusters from the Ordovician of Portugal // Geology. Vol.37. No.5. P.443-446.

Haug C., Rötzer M.A.I.N. 2018. The ontogeny of the 300 million year old xiphosuran Euproops danae (Euchelicerata) and im- 
plications for resolving the Euproops species complex // Development Genes and Evolution. Vol.228. No.1. P.63-74.

Hu S., Zhang Q., Feldmann R.M., Benton M.J., Schweitzer C.E., Huang J., Wen W., Zhou C., Xie T., Lu T., Hong S. 2017. Exceptional appendage and soft-tissue preservation in a Middle Triassic horseshoe crab from SW China // Scientific Reports. Vol.7. P.14112. DOI: 10.1038/s41598-017-13319.

Hughes N., Cooper D.L. 1999. Paleobiologic and taphonomic aspects of the "granulosa" trilobite cluster, Kope Formation (Upper Ordovician, Cincinnati region) // Journal of Paleontology. Vol.73. No.2. P.306-319.

Karim T., Westrop S.R. 2002. Taphonomy and paleoecology of Ordovician trilobite clusters, Bromide Formation, south-central Oklahoma // Palaios. Vol.17. No.4. P.394-402.

Kin A., Błażejowski B. 2014. The horseshoe crab of the genus Limulus: living fossil or stabilomorph? // PLoS ONE. Vol.9. No.10. P.e 108036

Latreille P.A. 1802. Histoire naturelle, générale et particulière, des crustacés et des insectes Paris: Dufart.

Leach W.E. 1819. Entomostraca // Levrault F. (ed.). Dictionaire des Science Naturelles. Paris: Levrault and Schoell. P.524-543

Linnaeus C. 1758. Systema naturæ per regna tria naturæ, secundum classes, ordines, genera, species, cum characteribus, differentiis, synonymis, locis. Holmia: Laurentius Salvius.

Meek F.B., Worthen A.H. 1865. Notice of some new types of organic remains, from the Coal Measures of Illinois // Proceedings of the Academy of Natural Sciences of Philadelphia Vol.17. No.1. P.41-48.

Mujal E., Belaústegui Z., Fortuny J., Bolet A., Oms O., López J.A. 2018. Ichnological evidence of a horseshoe crab hot-spot in the Early Triassic Buntsandstein continental deposits from the Catalan Pyrenees (NE Iberian Peninsula) // Journal of Iberian Geology. Vol.44. No.1. P.139-153.

Müller A.H. 1785. Entomostraca seu Insecta Testacea, quae in aquis Daniae et Norvegiae reperit, descripsit et iconibus illustravit .Leipzig and Copenhagen: Symtibus Bibliopolii J.G. Mülleriani, Müller, O.F. Lipsiae et Havniae.

Naugolnykh S.V. 2017. Lower Kungurian shallow-water lagoon biota of the Middle Cis-Urals, Russia: towards the paleoecological reconstruction// Global Geology. Vol.20. No.1. P.113.

Naugolnykh S.V. 2018. Main biotic and climatic events in Early Permian of the Western Urals, Russia, as exemplified by the shallow-water biota of the Kungurian lagoons // Palaeoworld. doi: $10.1016 /$ j.palwor.2018.10.002
Nopsca F.B. 1923. Die Familien der Reptilien // Fortschritte der Geologie und Paläontologie. Bd.2. S.1-210.

Paterson J.R., Hughes N.C., Chatterton B.D.E. 2008. Trilobite clusters: What do they tell us? A preliminary investigation. // Rábano I., Gozalo R., García-Bellido D. (eds). Advances in Trilobite Research. Madrid: Cuadernos del Museo Geominero 9, Instituto Geológico y Minero de España. Vol.9. P.313-318.

Pictet F.J. 1846. Traité élémentaire de paléontologie. Paris: Lanlois et Leclerq. T.4. $458 \mathrm{p}$.

Rudkin D.M., Young G.A. 2009. Horseshoe crabs - an ancient ancestry revealed // Tanacredi J.T., Botton M.L., Smith D.R. (eds.). Biology and Conservation of Horseshoe Crabs. Springer: New York. P.25-44

Rudkin D.M., Young G.A., Nowlan G.S. 2008. The oldest horseshoe crab: a new xiphosurid from Late Ordovician KonservatLagerstätten deposits, Manitoba, Canada // Palaeontology. Vol.51. No.1. P.1-9.

Shpinev E.S. 2017. New data on ecology of the Carboniferous limulids of Donets Basin // Palaeoecology. Methodological basis, factological potential, application for museum expositions. Moscow: Media-Grand. P.30-34.

Shuster Jr., C.N, Sekiguchi K. 2009. Basic habitat requirements of the extant species of horseshoe crabs (Limulacea) // Tanacredi J.T., Botton M.L., Smith D.R. (eds.). Biology and conservation of horseshoe crabs. New York: Springer. P.115-129.

Shuster Jr., C.N. 1982. A pictorial review of the natural history and ecology of the horseshoe crab Limulus polyphemus, with reference to other Limulidae // Progress in Clinical and Biological Research. Vol.81. P.1-52.

Speyer S.E., Brett C.E. 1985. Clustered trilobite assemblages in the Middle Devonian Hamilton group // Lethaia. Vol.18. No.2. P.85-103.

Tashman J.N., Feldmann R.M., Schweitzer C.E. 2019. Morphological variation in the Pennsylvanian horseshoe crab Euproops danae (Meek \& Worthen, 1865) (Xiphosurida, Euproopidae) from the lower Mercer Shale, Windber, Pennsylvania, USA // Journal of Crustacean Biology. Doi:10.1093/jcbiol/ruz030

Vrazo M.B., Braddy S.J. 2011. Testing the 'mass-moult-mate' hypothesis of eurypterid palaeoecology // Palaeogeography, Palaeoclimatology, Palaeoecology. Vol.311. No.1-2. P.63-73.

Zhang Q.Y., Hu S.X., Zhou C.Y., Lü T., Bai J.K. 2009. First occurrence of horseshoe crab (Arthropoda) fossils from China // Progress in Natural Science. Vol. 19. P.1090-1093.

Responsible editor K.G. Mikhailov

\section{Addition 1. Dataset of measurements used in Fig. 4. Дополнение 1. Промеры, использованные в рис. 4.}

Specimen number length of body (mm) Width of prosomal-opisthosomal joint (mm)

$\begin{array}{llc}\text { NHMUK PI In 61012 } & 24.8 & 20 \\ \text { NHMUK PI In 61013 } & 27.5 & 25.4 \\ \text { NHMUK PI In 61015 } & 24.8 & 21.8 \\ \text { NHMUK PI In 61016 } & 26.5 & 25.6 \\ \text { NHMUK PI In 61017 } & 24.7 & 27.9\end{array}$

